\title{
A meta-analysis of palliative treatment of pancreatic cancer with high intensity focused ultrasound
}

Susan Dababou ${ }^{1 * \dagger}$, Cristina Marrocchio ${ }^{1 \dagger}$, Jarrett Rosenberg ${ }^{2}$, Rachelle Bitton ${ }^{2}$, Kim Butts Pauly ${ }^{2}$, Alessandro Napoli ${ }^{3}$, Joo Ha Hwang ${ }^{4}$ and Pejman Ghanouni ${ }^{2}$

\begin{abstract}
Background: Pancreatic adenocarcinoma is currently the fourth-leading cause of cancer-related death. Up to 60-90\% of patients with advanced disease suffer cancer-related pain, severely impacting their quality of life. Current management involves primarily pharmacotherapy with opioid narcotics and celiac plexus neurolysis; unfortunately, both approaches offer transient relief and cause undesired side-effects. High intensity focused ultrasound (HIFU) is a non-invasive thermal ablation technique that has been used to treat pancreatic cancer. This meta-analysis aims to evaluate the role of HIFU in pain palliation of advanced unresectable pancreatic adenocarcinoma.
\end{abstract}

Methods: An electronic search was performed in PubMed Medline database up to the end of July 2016, for unresectable pancreatic cancer pain palliation with HIFU. Pertinent studies were identified through the PubMed search engine using the following keywords: HIFU, pancreas, pancreatic cancer, pain and palliation. Additional studies were included after manual search of the selected bibliographies. Pain palliation results reported in each study were analyzed using a logit-transformed random-effects model using the inverse variance method, with the DerSimonian-Laird estimator for $\tau^{2}$, and Cochran's $Q$ test for heterogeneity among studies. The $\mathrm{I}^{2}$ was calculated to assess the percentage of the total variability in the different effect size estimates that can be attributed to heterogeneity among the true effects. A rank correlation test of funnel plot asymmetry was done to assess possible publication bias.

Results: The meta-analysis includes a total number of 23 studies with 865 patients, 729 with pancreatic cancer. The population enrolled ranges from 3 patients in the smallest series, up to 61 in the largest study. $\tau^{2}$ (variance among studies) was 0.195 , and $\mathrm{I}^{2}$ (percentage of variation among studies) was $40 \%$ (95\% Cl: $1-64 \%$ ); the Q test p-value was 0. 026, indicating significant heterogeneity among studies. Among 639 patients treated with HIFU, 567 complained of pancreatic pain before the treatment and 459 patients experienced partial or complete pain relief after treatment. The random effects estimate of the proportion of patients with pain reduction was 0.81 (95\% Cl: 0.76-86).

\footnotetext{
* Correspondence: sdababou@gmail.com

${ }^{\dagger}$ Equal contributors

'Medical Student, Sapienza University of Rome, School of Medicine, V.le

Regina Elena, 324, 00180 Rome, Italy

Full list of author information is available at the end of the article
} 
(Continued from previous page)

Conclusions: HIFU appears to be an effective tool for pain palliation in advanced pancreatic cancer. Studies assessing treatment in patients with pancreatic adenocarcinoma are limited by factors such as small sample sizes and heterogeneity in clinical definitions and assessments. Prospective randomized and standardized studies are necessary to confirm the effectiveness of HIFU in relieving pain, and to evaluate for any potential impact on tumor control and patient survival.

Keywords: Pancreatic cancer, High intensity focused ultrasound, HIFU, Pain palliation, Pain relief, Non-invasive treatment, Meta-analysis

\section{Background}

Pancreatic cancer incidence is increasing worldwide with 53070 new cases and 41780 deaths estimated in 2016, and is currently the fourth cause of cancer-related death $[1,2]$. It more frequently affects men between 65 and 84 years of age and occurs predominantly in the Western countries, where environmental factors may play an important role in the pathogenesis [3]. Ductal pancreatic adenocarcinoma, the most common histology, accounts for $85-90 \%$ of these cancers [4].

Despite advances in diagnostic methods and the development of new therapeutic approaches, the prognosis for pancreatic cancer has remained dismal over the past 40 years [4], with an overall 5-year survival rate of less than $8 \%$, a median survival rate of $6-10$ months for unresectable, locally advanced disease, and 3 to 6 months for patients with metastases [5]. The only possibility of cure is through surgery; however, due to the late appearance of symptoms, less than $20 \%$ of patients present with resectable disease at the time of diagnosis [6]. Moreover, mortality remains high even after surgery due to the high locoregional recurrence rate and the tendency for early metastatic spread [7]. Considering the poor prognosis of these patients, the principal goals of pancreatic cancer therapy in advanced disease are to palliate symptoms and increase the overall survival. Throughout the illness and during end-of-life care, patients need comprehensive symptom control. Pain is common in patients with pancreatic cancer, and is reported by $60-90 \%$ of patients with advanced disease [8]. It is often described as dull pain, sometimes with colicky spasms, and is referred to the mid back or epigastric regions [9]. Gemcitabine-based chemotherapy and chemoradiation combinations produce a limited improvement in survival, but are not very effective in pain relief and are associated with high toxicity [10]. The current management of pancreatic cancer-related pain primarily involves pharmacotherapy with opioid narcotics and celiac plexus neurolysis. Unfortunately, opioid narcotics often cause undesired side effects ranging from mild constipation to altered mental status. In addition, some opioids can have a dysphoric effect that can significantly impact the patients' quality of life [11]. Celiac plexus neurolysis is performed in patients who have severe intractable pain that is poorly controlled on opioids; however, the procedure is invasive, requiring endoscopic ultrasound or CT-guidance. Initial uncontrolled and retrospective case series suggested that partial or complete pain relief was achieved in 70-90\% of patients undergoing neurolytic celiac plexus blockade (NCPB) [12]; however, a meta-analysis of five randomized controlled trials of NCPB demonstrated that the overall benefit was small, with only a $6 \%$ reduction in the mean visual analogue pain score compared to baseline [13]. Clearly, new methods are needed to both treat and palliate patients with advanced pancreatic cancer.

High intensity focused ultrasound (HIFU) is a noninvasive imaging-guided thermal ablation technique that uses an extracorporeal transducer to deliver ultrasound energy to induce an increase of temperature in a sharply demarcated region. Ultrasound or magnetic resonance imaging are used to assess the anatomy of the region for targeting and to provide real time feedback during ablation [14]. HIFU has a dual effect on the target tissue, inducing thermal and mechanical damage. During the treatment, the targeted tissue is heated to the $60-80{ }^{\circ} \mathrm{C}$ range within seconds, inducing liquefaction and coagulation necrosis in the targeted region, with the goal of thermal ablation of the tumor without affecting the surrounding healthy tissue $[14,15]$. The temperature reached is not high enough to cause an immediate necrosis of the cells, but it induces first intracellular denaturation of protein, and thus of the stored pancreatic enzymes, followed by cellular degeneration and necrosis. This "thermal fixation" phenomenon potentially reduces the risk of pancreatitis as a complication of the procedure [15]. In addition to thermal effects, there are three mechanical effects associated with high intensity acoustic energy: cavitation, microstreaming and radiation force. Cavitation results from the oscillating motion of gas-filled bubbles (stable cavitation); these bubbles coalesce and collapse under higher ultrasound field energy, causing a shock wave confined to the microenvironment (inertial cavitation) [16, 17]. Microstreaming is the consequence of stable cavitation occurring close to fluids, producing shear stress that transiently damages the cell membrane [18]. Lastly, 
radiation force results from the absorption or reflection of the acoustic waves by the encountered medium and can result in cellular apoptosis $[16,17]$.

We aim to examine the current literature on the role of HIFU in pain palliation in advanced pancreatic cancer and to compare the methodologies used for treatment, with the goal of providing a comprehensive resource of comparable data for the design of future studies.

\section{Methods}

\section{Article search}

A systematic electronic search was performed using the PubMed Medline database through July 2016. The electronic system was interrogated with the following keywords: "HIFU" AND "Pancreatic cancer", "HIFU" AND "Pain" AND "Pancreas", "HIFU" AND "Pain" AND "Pancreatic Cancer", "HIFU" AND "Palliation" AND "Pancreas"," HIFU" AND "Palliation" AND "Pancreatic Cancer". All variants of HIFU/high intensity focused ultrasound, pancreatic/pancreas, cancer/carcinoma, palliation/ palliative were searched. Because some of the research published in this area was not written in English, it does not appear in PubMed; therefore, a manual search of the bibliographies of selected studies and reviews was completed to supplement the electronic search.
The following exclusion criteria were applied: I) Reviews II) Studies not including pancreas III) Preclinical studies IV) Pain assessment not reported V) Reported imaging appearance or histology other than pancreatic adenocarcinoma VI) No primary pancreatic tumor VII) Studies with $\leq 2$ patients VIII) Papers analyzing more than one type of malignancy in which data specific for pancreatic cancer related pain was not reported. Fulltext articles were screened by SD, CM and PG. Translation of articles written in Chinese was provided by $\mathrm{JHH}$. The flow of selection is described using the Preferred Reporting Items for Systematic Reviews and MetaAnalyses (PRISMA) model [19]. (Fig. 1)

\section{Statistical analysis}

A meta-analysis of 23 studies on the therapeutic effect of HIFU on pancreatic cancer, defined as the proportion of patients having no or reduced pain post-procedure, was carried out. A logit-transformed random-effects model using the inverse variance method was used, with the DerSimonian-Laird estimator for $\tau^{2}$, and Cochran's $\mathrm{Q}$ test for heterogeneity among studies. The $\mathrm{I}^{2}$ was calculated to assess the percentage of the total variability in the different effect size estimates that can be attributed to heterogeneity among the true effects (substantial heterogeneity if $\mathrm{I}^{2}>50 \%$ ). A rank correlation test of funnel

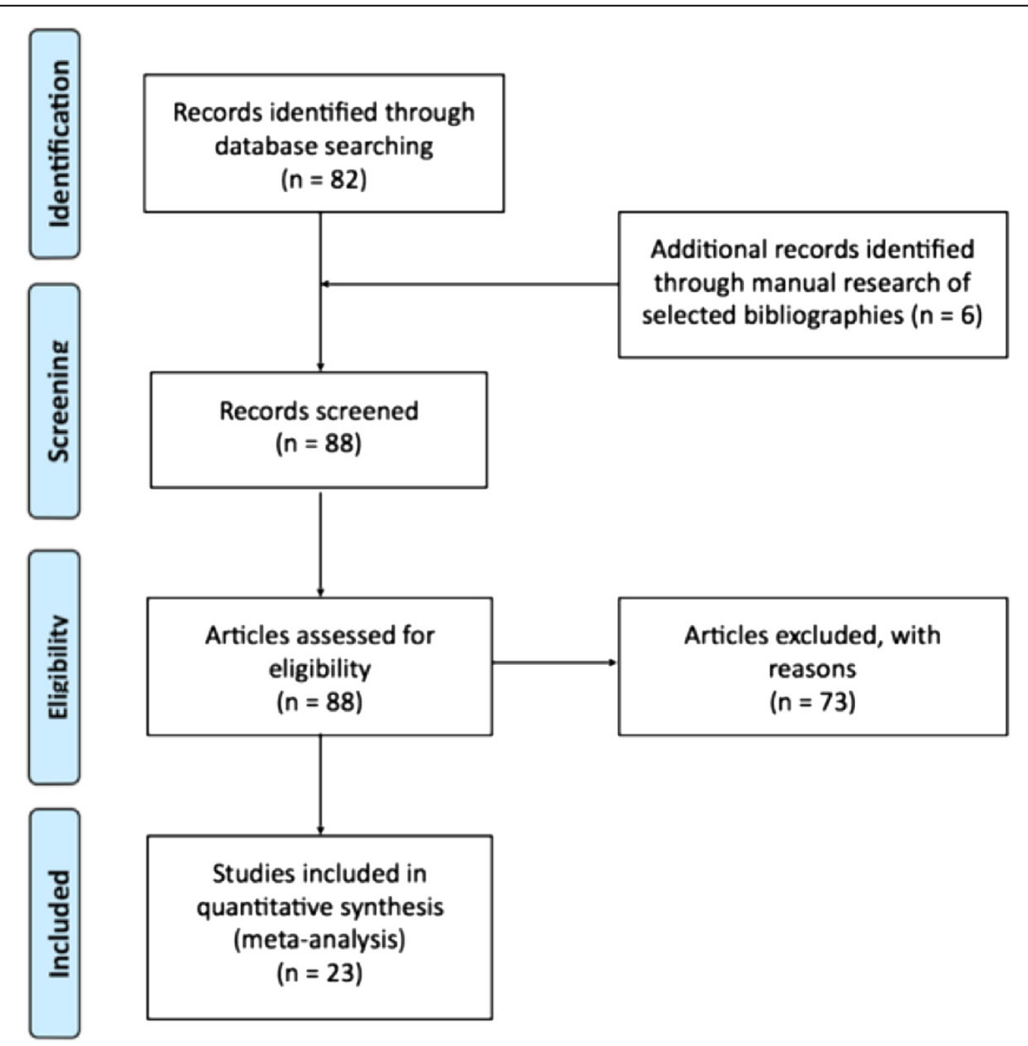

Fig. 1 PRISMA Flowchart. PRISMA, Preferred Reporting Items for Systematic Reviews and Meta-analyses 


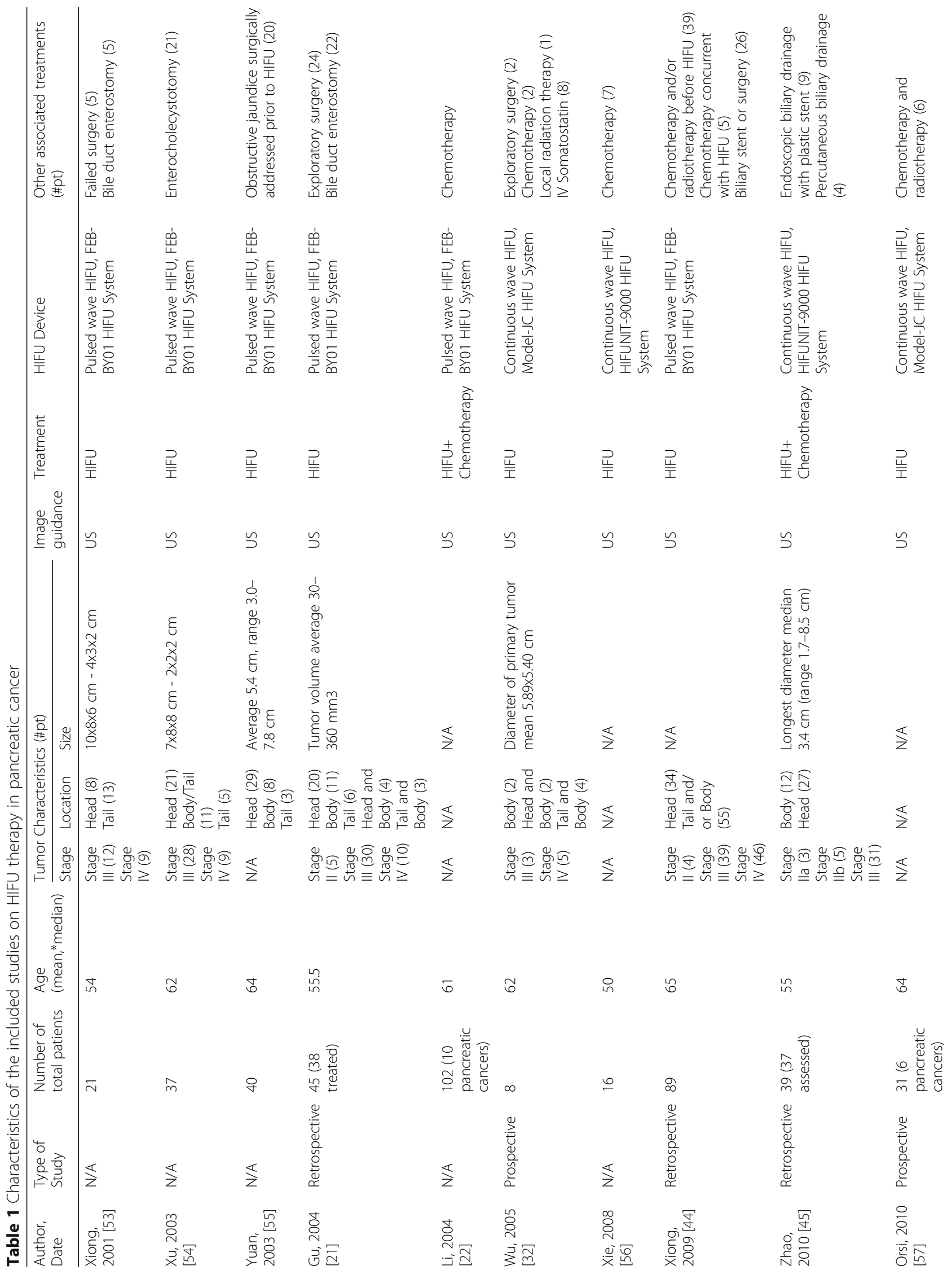




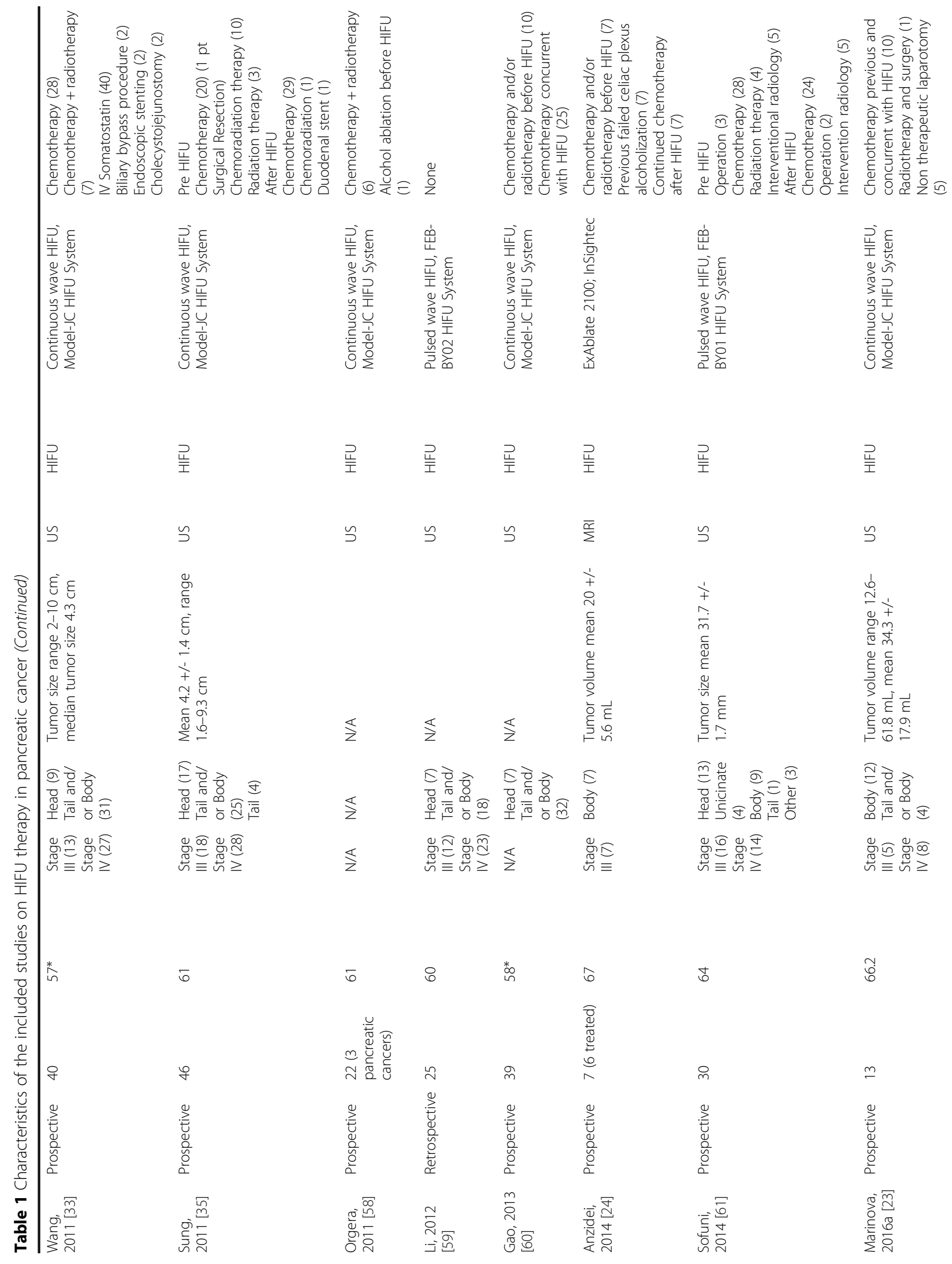


Dababou et al. Journal of Therapeutic Ultrasound (2017) 5:9

Page 6 of 16

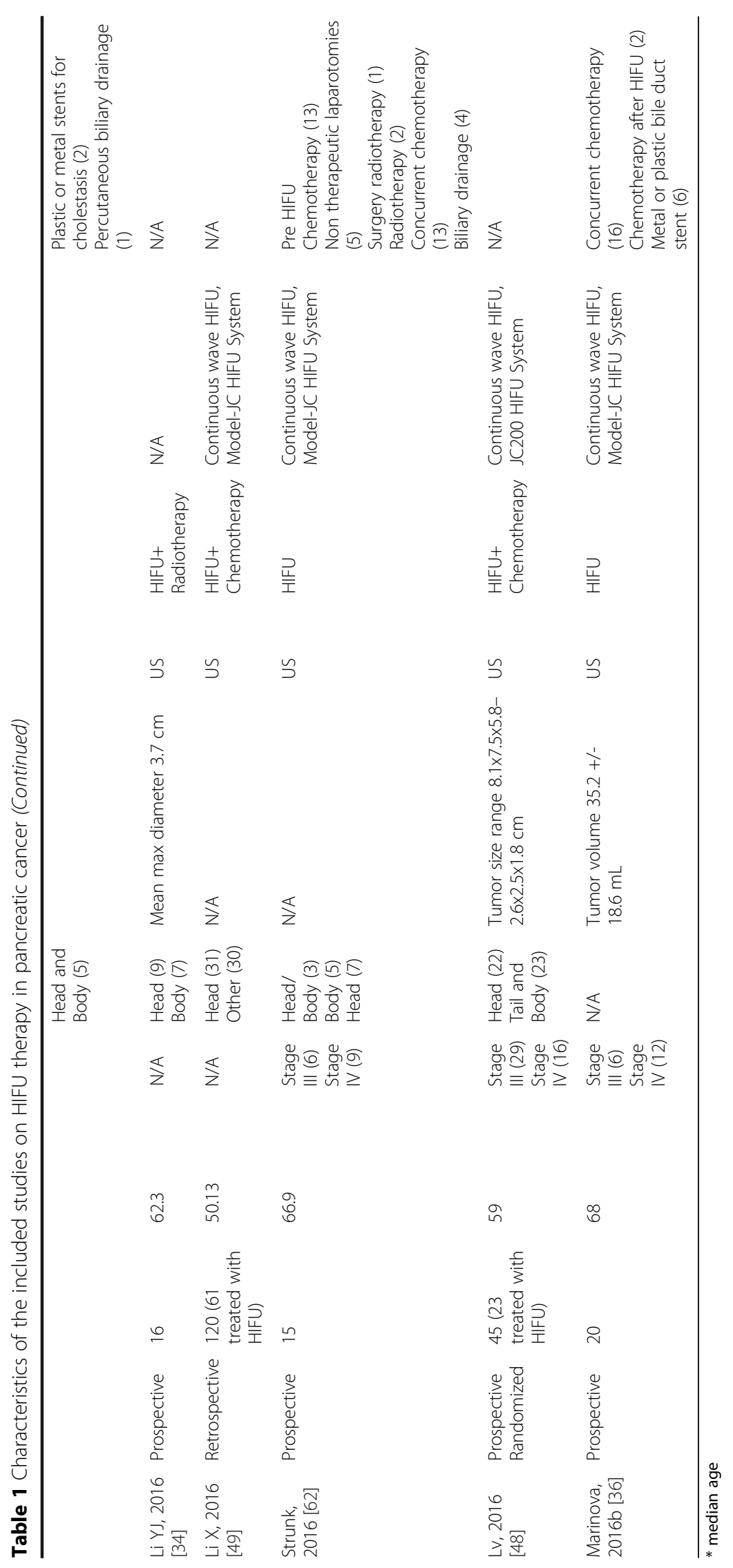


Table 2 Summary of the results of the included studies on HIFU therapy in pancreatic cancer

\begin{tabular}{|c|c|c|c|c|c|c|c|c|}
\hline \multirow{2}{*}{$\begin{array}{l}\text { Author, } \\
\text { Date }\end{array}$} & \multirow{2}{*}{$\begin{array}{l}\text { Pain } \\
\text { Evaluation }\end{array}$} & \multirow{2}{*}{$\begin{array}{l}\text { Number } \\
\text { of } \\
\text { patients } \\
\text { with } \\
\text { pain at } \\
\text { baseline }\end{array}$} & \multirow{2}{*}{$\begin{array}{l}\text { Number } \\
\text { of } \\
\text { patients } \\
\text { with } \\
\text { pain } \\
\text { relief }\end{array}$} & \multirow{2}{*}{$\begin{array}{l}\% \\
\text { Patients } \\
\text { with pain } \\
\text { reduction }\end{array}$} & \multicolumn{2}{|c|}{ Pain Scale 0-10 } & \multicolumn{2}{|l|}{ HIFU related adverse effects (\#pt) } \\
\hline & & & & & $\begin{array}{l}\text { Before } \\
\text { HIFU }\end{array}$ & $\begin{array}{l}\text { after } \\
\text { HIFU }\end{array}$ & Minor & Major \\
\hline $\begin{array}{l}\text { Xiong, } \\
2001[53]\end{array}$ & Pain Scale & 17 & 15 & 0.88 & $\begin{array}{l}7+/- \\
2.1\end{array}$ & $\begin{array}{l}3+/- \\
1.5\end{array}$ & None & Jaundice (1) \\
\hline $\begin{array}{l}\mathrm{Xu}, 2003 \\
{[54]}\end{array}$ & Pain Scale & 30 & 24 & 0.80 & $\begin{array}{l}5.6+/- \\
3.2\end{array}$ & $\begin{array}{l}2.0+/- \\
1.9\end{array}$ & Dilation of pancreatic duct with steatorrhea (3) & None \\
\hline $\begin{array}{l}\text { Yuan, } \\
2003[55]\end{array}$ & $\begin{array}{l}\text { Pain } \\
\text { Category }\end{array}$ & 40 & 32 & 0.80 & N/A & N/A & None & None \\
\hline $\begin{array}{l}\mathrm{Gu}, 2004 \\
{[21]}\end{array}$ & N/A & 38 & 36 & 0.95 & N/A & N/A & N/A & N/A \\
\hline $\begin{array}{l}\text { Li, } 2004 \\
{[22]}\end{array}$ & Pain Scale & 10 & 9 & 0.90 & N/A & N/A & Skin burn II (1) & None \\
\hline $\begin{array}{l}\text { Wu, } 2005 \\
{[32]}\end{array}$ & Drug Needs & 8 & 8 & 1.00 & N/A & N/A & None & None \\
\hline $\begin{array}{l}\text { Xie, } 2008 \\
{[56]}\end{array}$ & N/A & 16 & 14 & 0.88 & N/A & $\mathrm{N} / \mathrm{A}$ & Skin burn (1) & $\begin{array}{l}\text { Jaundice } \\
\text { aggravation(1) }\end{array}$ \\
\hline $\begin{array}{l}\text { Xiong, } \\
2009[44]\end{array}$ & Pain Scale & 67 & 54 & 0.81 & N/A & $\mathrm{N} / \mathrm{A}$ & $\begin{array}{l}\text { Skin burn II (3), Subcutaneous sclerosis (6), } \\
\text { Pancreatic pseudocyst (1) }\end{array}$ & None \\
\hline $\begin{array}{l}\text { Zhao, } \\
2010[45]\end{array}$ & $\begin{array}{l}\text { VAS + Use } \\
\text { of opioids }\end{array}$ & 28 & 22 & 0.79 & N/A & N/A & None & None \\
\hline $\begin{array}{l}\text { Orsi, } 2010 \\
{[57]}\end{array}$ & N/A & 6 & 5 & 0.83 & N/A & N/A & None & $\begin{array}{l}\text { Portal Vein } \\
\text { Thrombosis (1) }\end{array}$ \\
\hline $\begin{array}{l}\text { Wang, } \\
2011[33]\end{array}$ & Pain Scale & 40 & 35 & 0.88 & N/A & N/A & None & None \\
\hline $\begin{array}{l}\text { Sung, } \\
2011[35]\end{array}$ & VAS & 25 & 24 & 0.96 & $\begin{array}{l}4.9+/- \\
1.1 \\
\text { range } \\
4-9\end{array}$ & $\begin{array}{l}2.1+/- \\
1.1 \\
\text { range } \\
0-5\end{array}$ & $\begin{array}{l}\text { Mild abdominal pain (16), Transient pancreatitis } \\
\text { (7), Transient fever (3), Severe abdominal pain } \\
\text { with vomiting (2) }\end{array}$ & $\begin{array}{l}\text { Pancreaticoduodenal } \\
\text { fistula (2),Skin burn II } \\
\text { (1), Skin burn III (1) }\end{array}$ \\
\hline $\begin{array}{l}\text { Orgera, } \\
2011[58]\end{array}$ & $\begin{array}{l}\text { Use of } \\
\text { opioids }\end{array}$ & 3 & 3 & 1.00 & N/A & N/A & None & None \\
\hline $\begin{array}{l}\mathrm{Li}, 2012 \\
{[59]}\end{array}$ & Pain scale & 25 & 23 & 0.92 & $\begin{array}{l}4.6+/- \\
2.1\end{array}$ & $\begin{array}{l}2.2+/- \\
0.9\end{array}$ & Skin burn I (3) & None \\
\hline $\begin{array}{l}\text { Gao, } 2013 \\
{[60]}\end{array}$ & Pain Scale & 39 & 31 & 0.79 & $\mathrm{~N} / \mathrm{A}$ & $\mathrm{N} / \mathrm{A}$ & None & None \\
\hline $\begin{array}{l}\text { Anzidei, } \\
2014[24]\end{array}$ & Pain Scale & 6 & 6 & 1.00 & $7+/-1$ & $3+/-1$ & None & None \\
\hline $\begin{array}{l}\text { Sofuni, } \\
2014[61]\end{array}$ & Pain Scale & 21 & 16 & 0.76 & $\mathrm{~N} / \mathrm{A}$ & $\mathrm{N} / \mathrm{A}$ & Mild pancreatitis (1) Pseudocyst formation (2) & None \\
\hline $\begin{array}{l}\text { Marinova, } \\
\text { 2016a [23] }\end{array}$ & Pain Scale & 13 & 10 & 0.77 & N/A & N/A & $\begin{array}{l}\text { Mild to severe abdominal pain (7), Skin burn II } \\
\text { (1), Induration subcutaneous fat tissue (1), Local } \\
\text { edema (6), Increase in pancreatic lipase (3) }\end{array}$ & $\begin{array}{l}\text { Severe abdominal } \\
\text { pain requiring } \\
\text { hospitalisation (1) }\end{array}$ \\
\hline $\begin{array}{l}\text { Li YJ, } \\
2016[34]\end{array}$ & Pain Scale & 16 & 15 & 0.94 & $\begin{array}{l}5.1+/- \\
2.2\end{array}$ & 3.3 & None & None \\
\hline $\begin{array}{l}\text { Li X, } 2016 \\
{[49]}\end{array}$ & Pain Scale & 61 & 35 & 0.57 & 6 & N/A & Slight skin burns & None \\
\hline $\begin{array}{l}\text { Strunk, } \\
2016[62]\end{array}$ & $\begin{array}{l}\text { Pain Scale } \\
+ \text { Use of } \\
\text { opioids }\end{array}$ & 15 & 12 & 0.80 & N/A & N/A & $\begin{array}{l}\text { Transient subcutaneous edema (9), Skin burn II } \\
\text { (1), Subcutaneous sclerosis (1), Lipase increase (3) }\end{array}$ & None \\
\hline \multirow[t]{2}{*}{$\begin{array}{l}\text { Lv, } 2016 \\
{[48]}\end{array}$} & $\begin{array}{l}\text { Memorial } \\
\text { Pain } \\
\text { Assessment } \\
\text { Card }\end{array}$ & 23 & 15 & 0.65 & N/A & $\mathrm{N} / \mathrm{A}$ & None & None \\
\hline & Pain Scale & 20 & 15 & 0.75 & & & & None \\
\hline
\end{tabular}


Table 2 Summary of the results of the included studies on HIFU therapy in pancreatic cancer (Continued)

Marinova,

$2016 b$

[36]

$\begin{array}{lll}3.75 & 1.60 & \text { Mild severe abdominal pain (13), Cutaneous/ } \\ +/- & +/- & \text { subcutaneous edema (11), Subcutaneous tissue } \\ 2.07 & 1.35 & \begin{array}{l}\text { induration (1), Skin burn Ila (1), Increase in lipase } \\ \text { (3) }\end{array}\end{array}$

(3) plot asymmetry was done to assess possible publication bias. All statistical analyses were done with $\mathrm{R} 3.1 .2$ and version 4.4.0 of the "meta" package (r-project.org).

\section{Results}

\section{Search results and characteristics of the included studies}

The primary electronic search identified 82 articles. Following the application of the exclusion criteria and the unavailability of one paper [20], 17 studies were selected. Six further studies were added from the manual research, five of which were translated from the Chinese language. A total of 23 studies were included in the statistical analysis. Studies were published between 2001 and 2016. Sixteen studies were from China, three from Italy, three from Germany, and one from Japan.

The demographic and clinical data are listed in Table 1. The studies include a total number of 865 patients; 729 had pancreatic cancer, of which 639 underwent HIFU treatment. The population enrolled ranges from 3 patients in the smallest series, up to 61 in the largest study. All 729 pancreatic cancers included were deemed unresectable. Three out of 20 papers were not limited to pancreatic cancer but also included other abdominal or pelvic malignancies. In 4 papers HIFU was combined with chemotherapy ( 2 with Gemcitabine, 1 with S-1 and in 1 is not specified), in 1 with radiotherapy and in the other 16 papers focused ultrasound was variably associated with prior chemotherapy and/or radiotherapy. In two clinical studies the patients were divided into two groups, comparing chemotherapy alone to a combination treatment including HIFU. MRI guidance was performed only in one study; the others used B-mode ultrasound.

\section{Clinical outcome}

Among 639 patients treated with HIFU, 567 complained of pancreatic pain before the treatment. After HIFU, 459 patients experienced a partial or complete pain relief (Table 2). The random effects estimate of proportion of patients with pain reduction was 0.81 (95\% CI: 0.76-86) (Fig. 2). Based on this result, we can conclude that $81 \%$ of patients may expect to have pain relief after HIFU treatment, notwithstanding that we have to take into consideration the variability among the studies. Therefore, the lower boundary of $76 \%$ is a more conservative, and probably more valid, estimate of the true value.

The $\mathrm{I}^{2}$ of the included studies was $40 \%$ (95\% CI: $\left.1-64 \%\right)$. This result indicates that multiple effect sizes are possibly

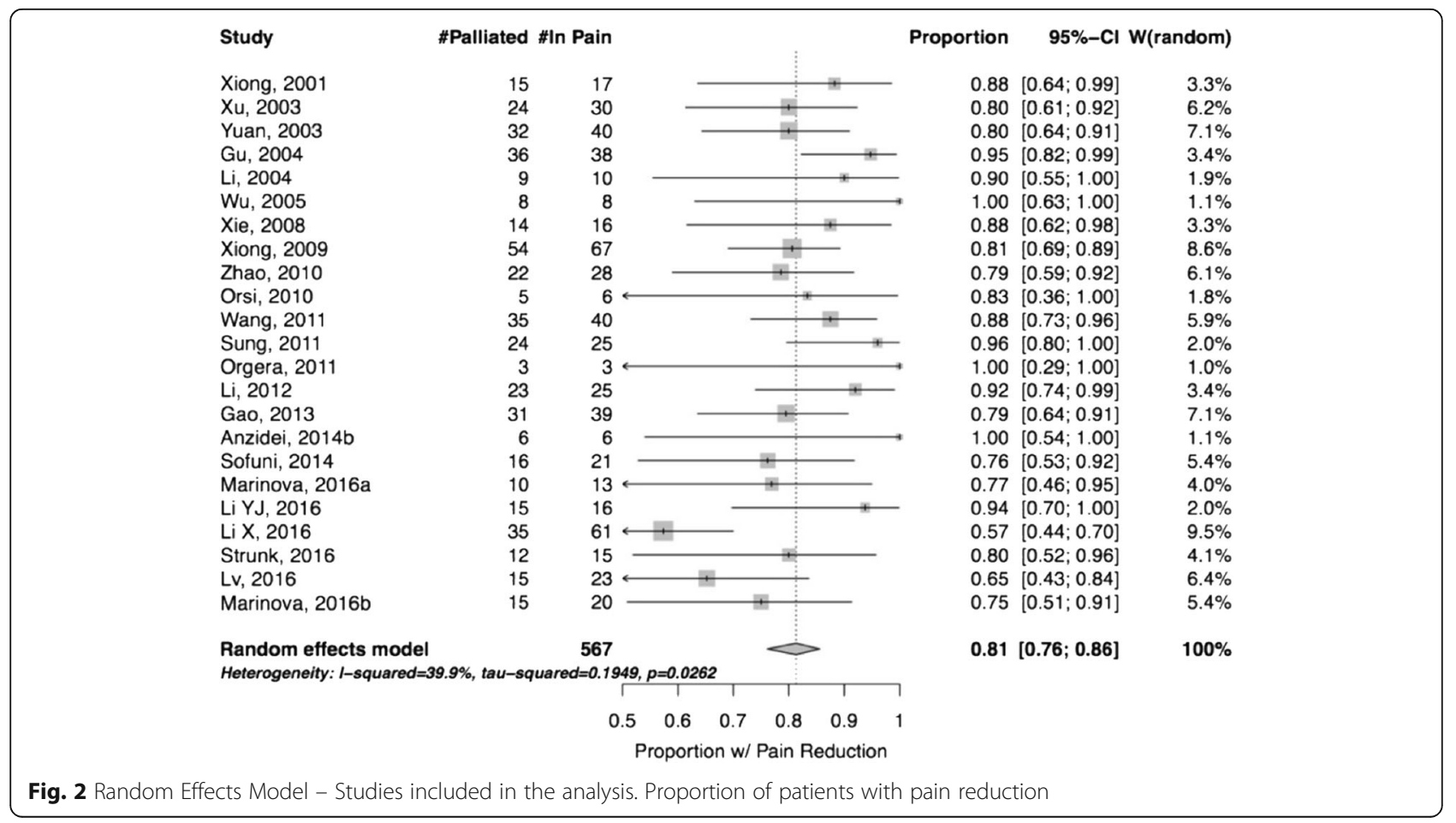




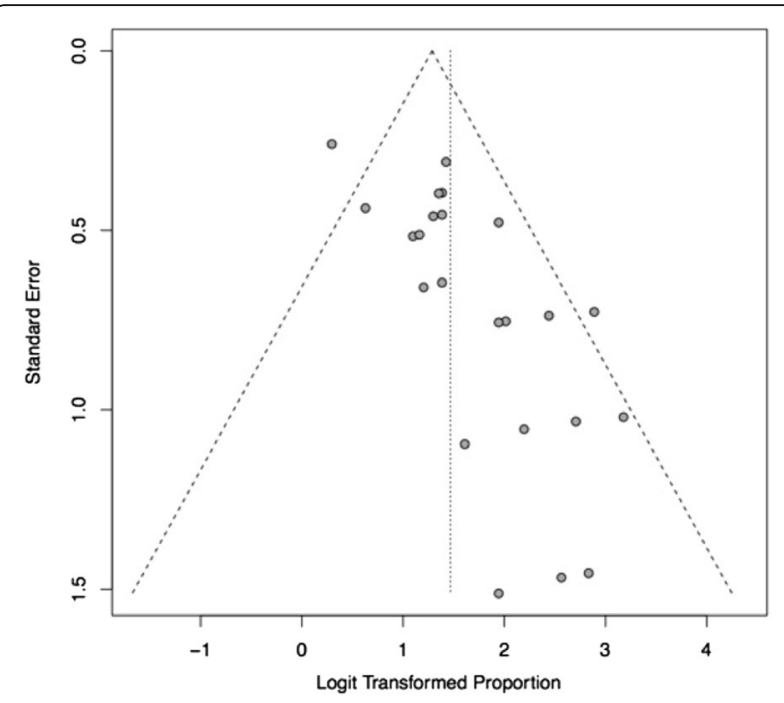

Fig. 3 Funnel plot demonstrating possible but not statistically significant publication bias in assessment of pain $(P>0.05)$. -Dashed diagonal lines indicate 95\% Cl

present, most probably because of the considerable variability in patients, treatments and other parameters in the publications. In fact, the $\mathrm{Q}$ test $\mathrm{p}$-value was 0.026 , confirming a significant heterogeneity among studies, as shown in Fig. 2. The funnel plot (Fig. 3) suggests a possible publication bias, with small less-successful studies missing, but the test of asymmetry was not statistically significant $(p=0.054)$.

Pain evaluation was heterogeneous among the studies, and the follow up periods were not consistent, with different or not specified assessment intervals. Eighteen studies used a quantitative estimate of the pain, adopting a numerical scale, VAS (Visual Analog Scale) or NRS (Numerical Range Scale) ranging from 0 to 10, with ten defined as the maximum pain experienced and 0 no pain reported. The associated use of painkillers was variably included in the definition of pain relief; although most of the patients reduced or discontinued the use of analgesic medications, it is not possible to quantify this rate due to heterogeneous reporting of the details of opioid analgesia in these papers.

The tumor response was not part of the statistical analysis since there were no uniform criteria, methodology and timing of evaluation among the studies. The modality of assessment and the number of patients with a tumor response after ultrasound ablation are summarized in Table 3. The most common criteria for the evaluation of a positive response were: changes in grey scale on US, RECIST (Response Evaluation Criteria in Solid Tumors) guidelines, WHO criteria, lack of contrast enhancement, lack of vascularity and reduction in size. With MRgFUS the Non Perfused Volume on MRI images was evaluated using $60 \%$ as threshold to define an efficacious treatment. Excluding two studies that did not report the data, $74 \%$ of the patients treated with HIFU had a positive tumor response.

The most commonly encountered mild adverse events following HIFU were mild to severe abdominal pain $(n=38,5.9 \%)$, followed by edema $(n=26,4.1 \%)$ and first and second degree skin burns $(n=11,1.7 \%)$. Only eight cases of severe complications were reported $(1,2 \%)$. (Table 2).

\section{HIFU Technique}

Preoperatively, a medical history, physical examination and biochemical laboratory blood tests were collected. The preparation of the patient differed among the studies. The most common procedures are reported. Before HIFU the patient underwent bowel preparation with $12-24 \mathrm{~h}$ fasting. Abdominal skin was prepared in order to avoid local skin burns with shaving and cleaning of the area. A pad located between the transducer and the patient's abdomen was used to displace bowel loops from the US beam pathway. Additional procedures were: laxatives, liquid diet, traditional Chinese medication [21, 22], and a stomach tube to administer antifoaming agents and bind air bubbles [23]. If necessary, biliary stenting or a cholecystojejunostomy was performed to prevent or relieve the presence of obstructive jaundice.

Most of the studies included used US-guided HIFU devices, either the JC Model (Chongqing HIFU Technology Co, Ltd., Chongqing, China) or the FEB-BY HIFU system (Yuande Biomedical Engineering Limited Corporation, Beijing, China) (Table 1). Both systems use ultrasonography to visualize the tumor and to monitor tumor ablation; the main difference between these two is in the pattern of delivery and intensity of the ultrasound waves. The JC Model system delivers continuous wave focused ultrasound with high intensity, in the $5-20 \mathrm{~kW} / \mathrm{cm}^{2}$ range, that allows a unique session treatment but requires sedation or general anesthesia and hospitalization of the patient. The FEB-BY system employs pulsed-wave focused ultrasound with low intensities, less than $3 \mathrm{~kW} / \mathrm{cm}^{2}$. This results in the need for more than one treatment session per patient (from 4 to 7 ), but most treatments do not require sedation or hospitalization (Table 4) [18]. One study used an MRgFUS device (ExAblate 2100; InSightec, Haifa, Israel), performing all the procedures on a 3-T MRI scanner. The frequencies of the system range from 0.95 to $1.35 \mathrm{MHz}$, and the energy from 100 to $7200 \mathrm{~J}$. The treatment was performed under general anesthesia with controlled respiration to overcome motion artifacts [24]. Overall, procedures were performed under different conditions of analgesia: 8 studies administered general anesthesia, 3 used sedative analgesia, 1 regional anesthesia and 3 patients had epidural anesthesia. 6 studies did not use any anesthetic and 5 papers did not report this 
Table 3 Tumor response

\begin{tabular}{|c|c|c|c|c|c|c|c|}
\hline \multirow{2}{*}{$\begin{array}{l}\text { Author, } \\
\text { date }\end{array}$} & \multicolumn{3}{|l|}{ Tumor response } & \multirow{2}{*}{$\begin{array}{l}\text { Complete } \\
\text { response }\end{array}$} & \multirow{2}{*}{$\begin{array}{l}\text { Partial } \\
\text { response }\end{array}$} & \multirow{2}{*}{$\begin{array}{l}\text { Stable } \\
\text { disease }\end{array}$} & \multirow{2}{*}{$\begin{array}{l}\text { Progressive } \\
\text { disease }\end{array}$} \\
\hline & Imaging evaluation method & Parameter evaluated & $\begin{array}{l}\text { Result } \\
\text { \#pt }\end{array}$ & & & & \\
\hline $\begin{array}{l}\text { Xiong, } \\
2001[53]\end{array}$ & US & hyperechogenicity & 21 & & & & \\
\hline $\begin{array}{l}\mathrm{Xu}, 2003 \\
{[54]}\end{array}$ & US & hypovascularity & 12 & & & & \\
\hline $\begin{array}{l}\text { Yuan, } 2003 \\
{[55]}\end{array}$ & $C T$, US, CDFI & N/A & 36 & 8 & 28 & 0 & 4 \\
\hline $\begin{array}{l}\text { Gu, } 2004 \\
{[21]}\end{array}$ & CDFI & N/A & N/A & & & & \\
\hline $\begin{array}{l}\text { Li, } 2004 \\
{[22]}\end{array}$ & $\begin{array}{l}C T, \text { US,CDFI, pathological } \\
\text { analysis only in the effective }\end{array}$ & $\begin{array}{l}\text { reduction in tumor size, hyperechogenicity, blood } \\
\text { flow decrease/disappearance }\end{array}$ & 9 & & & & \\
\hline $\begin{array}{l}\text { Wu, } 2005 \\
{[32]}\end{array}$ & $\mathrm{CT}$ or MRI & tumor reduction rate (range $20-70 \%$ ) & 8 & & & & \\
\hline $\begin{array}{l}\text { Xie, } 2008 \\
{[56]}\end{array}$ & US & hyperchogenicity & 15 & & & & \\
\hline $\begin{array}{l}\text { Xiong, } \\
2009[44]\end{array}$ & $\mathrm{CT}$ or MRI & absence of perfusion & 64 & & & & \\
\hline $\begin{array}{l}\text { Zhao, } 2010 \\
\text { [45] }\end{array}$ & $\mathrm{CT}$ & RECIST & 32 & 2 & 15 & 15 & 5 \\
\hline $\begin{array}{l}\text { Orsi, } 2010 \\
{[57]}\end{array}$ & $\mathrm{PET} / \mathrm{CT}, \mathrm{CT}$ or MRI & $\begin{array}{l}\text { focal uptake of FDG, low attenuation at the } \\
\text { ablation site without contrast enhancement at the } \\
\text { edges }\end{array}$ & 5 & & & & \\
\hline $\begin{array}{l}\text { Wang, } \\
2011[33]\end{array}$ & CT & decreased enhancement & 35 & 0 & 7 & 28 & 5 \\
\hline $\begin{array}{l}\text { Sung, } 2011 \\
{[35]}\end{array}$ & MRI & stack model (unenhanced area) & 46 & & & & \\
\hline $\begin{array}{l}\text { Orgera, } \\
2011[58]\end{array}$ & $\mathrm{PET} / \mathrm{CT}$ or MRI, US, CT & $\begin{array}{l}\text { lack of contrast and enhancement of metabolic } \\
\text { activity }\end{array}$ & 3 & & & & \\
\hline $\begin{array}{l}\mathrm{Li}, 2012 \\
{[59]}\end{array}$ & US, CT & $\begin{array}{l}\text { hyperechogenicity, and hypovascularity(US), tumor } \\
\text { necrosis and reduction (CT) }\end{array}$ & 18 & & & & \\
\hline $\begin{array}{l}\text { Gao, } 2013 \\
{[60]}\end{array}$ & $\mathrm{CT}$ or MRI & $\begin{array}{l}\text { decrease or disappearance of blood supply in } \\
\text { target region and circular enhancement in tumor } \\
\text { periphery }\end{array}$ & 30 & 0 & 5 & 25 & 9 \\
\hline $\begin{array}{l}\text { Anzidei, } \\
2014[24]\end{array}$ & $\mathrm{CT}$ and $\mathrm{MRI}$ & $\begin{array}{l}\text { changes in density and intensity, contrast } \\
\text { enhancement, non perfused volume (at least 60\%) }\end{array}$ & 6 & & & & \\
\hline $\begin{array}{l}\text { Sofuni, } \\
2014 \text { [61] }\end{array}$ & CT & WHO criteria & 26 & 0 & 4 & 22 & 4 \\
\hline $\begin{array}{l}\text { Marinova, } \\
\text { 2016a [23] }\end{array}$ & US & lack of contrast enhancement & 13 & & & & \\
\hline $\begin{array}{l}\text { Li YJ, } 2016 \\
\text { [34] }\end{array}$ & $\mathrm{MRI}, \mathrm{CT}, \mathrm{US}$ & RECIST & 11 & 0 & 7 & 4 & 5 \\
\hline $\begin{array}{l}\text { Li X, } 2016 \\
\text { [49] }\end{array}$ & CT & RECIST & 16 & 1 & 15 & N/A & $\mathrm{N} / \mathrm{A}$ \\
\hline $\begin{array}{l}\text { Strunk, } \\
2016 \text { [62] }\end{array}$ & US, CT, MRI & tumor ablation rate (NPV/total volume) & 8 & & & & \\
\hline $\begin{array}{l}\text { LV, } 2016 \\
{[48]}\end{array}$ & CT & RECIST & 18 & 0 & 10 & 8 & 0 \\
\hline $\begin{array}{l}\text { Marinova, } \\
\text { 2016b [36] }\end{array}$ & $\mathrm{CT}$ and $\mathrm{MRI}$ & tumor volume reduction & N/A & & & & \\
\hline
\end{tabular}

FDG flurodeoxyglucose, NPV non perfused volume, CDFI color doppler flow imaging, RECIST response evaluation criteria in solid tumors 
Table 4 HIFU Technical parameters

\begin{tabular}{|c|c|c|c|c|c|c|}
\hline $\begin{array}{l}\text { Author, } \\
\text { date }\end{array}$ & $\begin{array}{l}\text { HIFU } \\
\text { device }\end{array}$ & HIFU Transducer features & $\begin{array}{l}\text { Intensity and } \\
\text { frequency }\end{array}$ & $\begin{array}{l}\text { Acoustic } \\
\text { output power }\end{array}$ & $\begin{array}{l}\text { Continuous } \\
\text { or pulsed } \\
\text { wave }\end{array}$ & Number of sessions \\
\hline $\begin{array}{l}\text { Xiong, } \\
2001[53]\end{array}$ & $\begin{array}{l}\text { FEB-BY01 } \\
\text { HIFU } \\
\text { System }\end{array}$ & N/A & N/A & $\begin{array}{l}\text { input power: } \\
1-2 \mathrm{~kW}\end{array}$ & pulsed & 9.5 average, max 15 \\
\hline $\begin{array}{l}\mathrm{Xu}, 2003 \\
{[54]}\end{array}$ & $\begin{array}{l}\text { FEB-BY01 } \\
\text { HIFU } \\
\text { System }\end{array}$ & N/A & N/A & $\begin{array}{l}\text { input power: } \\
1-2 \mathrm{~kW}\end{array}$ & pulsed & 6.5 average, $\max 12$ \\
\hline $\begin{array}{l}\text { Yuan, } \\
2003[55]\end{array}$ & $\begin{array}{l}\text { FEB-BY01 } \\
\text { HIFU } \\
\text { System }\end{array}$ & $\begin{array}{l}\text { effective treatment depth } 3.5- \\
14.0 \mathrm{~cm} \text {; practice focused sphere } \\
0.3 \times 0.3 \times 0.8 \mathrm{~cm} \text {; effective focused } \\
\text { sphere of } 0.6 \times 0.6 \times 0.6 \mathrm{~cm}\end{array}$ & N/A & $1-2 \mathrm{~kW}$ & pulsed & $\begin{array}{l}40 \text { patients received in total } \\
\text { more than } 280 \text { HIFU treatments } \\
\text { ( } 2-4 \text { times for smaller tumour } \\
\text { focus) }\end{array}$ \\
\hline $\begin{array}{l}\text { Gu, } 2004 \\
{[21]}\end{array}$ & $\begin{array}{l}\text { FEB-BY01 } \\
\text { HIFU } \\
\text { System }\end{array}$ & $\begin{array}{l}\text { depth of effective therapy } 2-15 \mathrm{~cm} \text {; } \\
\text { actual focus measurement } 0.3 \times \\
0.3 \times 0.8 \mathrm{~cm} \text {; effective focus of } 0.6 \times \\
0.6 \times 1 \mathrm{~cm}\end{array}$ & N/A & $\begin{array}{l}1-2 \mathrm{~kW} \\
\text { average: } \\
1.5 \mathrm{~kW}\end{array}$ & pulsed & 6 average (range 3-14) \\
\hline $\begin{array}{l}\text { Li, } 2004 \\
{[22]}\end{array}$ & $\begin{array}{l}\text { FEB-BY02 } \\
\text { HIFU } \\
\text { System }\end{array}$ & $\begin{array}{l}\text { effective therapy depth of } 2-15 \mathrm{~cm} \text {; } \\
\text { practice focused sphere of } 0.3 \times \\
0.3 \times 0.8 \mathrm{~cm} \text {; effective focused } \\
\text { sphere } 0.6 \times 0.6 \times 1 \mathrm{~cm}\end{array}$ & N/A & $1-2 \mathrm{~kW}$ & pulsed & $\begin{array}{l}8.4 \text { average (range } 5-12 \text { ). Patients } \\
\text { with abdominal and back pain } \\
\text { got abdominal ganglion } \\
\text { treatment } 1-2 \text { times per patient }\end{array}$ \\
\hline $\begin{array}{l}\text { Wu, } 2005 \\
{[32]}\end{array}$ & $\begin{array}{l}\text { Model-JC } \\
\text { HIFU } \\
\text { System }\end{array}$ & $\begin{array}{l}12 \mathrm{~cm} \text { diameter; focal length } \\
13.5 \mathrm{~cm} \text {; focal region: } 9.8 \mathrm{~mm} \text { along } \\
\text { beam axis, } 1.3 \mathrm{~mm} \text { in transverse } \\
\text { direction }\end{array}$ & $\begin{array}{l}0.8 \mathrm{MHz} \text {; Acoustic } \\
\text { focal peak intensity: } \\
10 \text { to } 15 \mathrm{~kW} / \mathrm{cm} 2\end{array}$ & N/A & continuous & $\begin{array}{l}1.5 \text { average ( } 2 \text { patients had } 2 \\
\text { sessions, } 6 \text { patients had } 1 \\
\text { session) }\end{array}$ \\
\hline $\begin{array}{l}\text { Xie, } 2008 \\
{[56]}\end{array}$ & $\begin{array}{l}\text { HIFUNIT- } \\
9000 \\
\text { HIFU } \\
\text { System }\end{array}$ & $\begin{array}{l}\text { effective therapy depth: } 17 \mathrm{~cm} \text {; } \\
\text { focused sphere: } 0.3 \times 0.3 \times 0.8 \mathrm{~cm}\end{array}$ & $1 \mathrm{MHz}$ & $\begin{array}{l}\text { maximum } \\
\text { output power: } \\
600 \mathrm{~W} \text { in the } \\
\text { study: 200- } \\
300 \mathrm{~W}\end{array}$ & continuous & 4.25 average (range $2-8$ ) \\
\hline $\begin{array}{l}\text { Xiong, } \\
2009[44]\end{array}$ & $\begin{array}{l}\text { FEB-BY } \\
\text { HIFU } \\
\text { System }\end{array}$ & $\begin{array}{l}\text { overall aperture } 37 \mathrm{~cm} \text {; focal length } \\
26 \mathrm{~cm} \text {; }-6 \mathrm{~dB} \text { focal dimensions: } \\
0.8 \mathrm{~cm} \text { in length, } 0.3 \mathrm{~cm} \text { in diameter }\end{array}$ & $1.04 \mathrm{MHz}$ & $250-430 \mathrm{~W}$ & pulsed & 4-10 sessions \\
\hline $\begin{array}{l}\text { Zhao, } \\
2010 \text { [45] }\end{array}$ & $\begin{array}{l}\text { HIFUNIT- } \\
9000 \\
\text { HIFU } \\
\text { System }\end{array}$ & $\begin{array}{l}\text { effective therapy depth } 2-15 \mathrm{~cm} \text {; } \\
\text { practice focused sphere } 0.3 \times 0.3 \times \\
1 \mathrm{~cm}\end{array}$ & N/A & $\begin{array}{l}\text { Input power: } \\
3 \mathrm{~kW} / \mathrm{cm} 2\end{array}$ & continuous & $\begin{array}{l}\text { Gemcitabine on days } 1,8 \text { and } 15, \\
\text { and multiple HIFU sessions on } \\
\text { days } 1,3 \text { and } 5 \text {. The combined } \\
\text { treatment repeated every } 28 \\
\text { days }\end{array}$ \\
\hline $\begin{array}{l}\text { Orsi, } 2010 \\
{[57]}\end{array}$ & $\begin{array}{l}\text { Model-JC } \\
\text { HIFU } \\
\text { System }\end{array}$ & $20 \mathrm{~cm}$ diameter; focal length $15 \mathrm{~cm}$ & $0.8 \mathrm{MHz}$ & 200-400 W & continuous & single session \\
\hline $\begin{array}{l}\text { Wang, } \\
2011[33]\end{array}$ & $\begin{array}{l}\text { Model-JC } \\
\text { HIFU } \\
\text { System }\end{array}$ & $\begin{array}{l}20 \mathrm{~cm} \text { diameter, focal length } \\
13.5 \mathrm{~cm} \text {; focal region: } 8 \mathrm{~mm} \text { along } \\
\text { beam axis, } 1.5 \mathrm{~mm} \text { in transverse } \\
\text { direction }\end{array}$ & $0.85 \mathrm{MHz}$ & $\begin{array}{l}\text { mean power } \\
\text { range: } 117- \\
388 \mathrm{~W} \\
\text { median: } \\
247 \mathrm{~W}\end{array}$ & continuous & single session \\
\hline $\begin{array}{l}\text { Sung, } \\
2011 \text { [35] }\end{array}$ & $\begin{array}{l}\text { Model-JC } \\
\text { HIFU } \\
\text { System }\end{array}$ & $\begin{array}{l}20 \mathrm{~cm} \text { diameter; system operated by } \\
\text { using one of several therapeutic } \\
\text { transducers with focusing lengths } \\
\text { that varied from } 9 \text { to } 16 \mathrm{~cm}(13.7 \mathrm{~cm} \\
\text { focusing length most used in the } \\
\text { study) }\end{array}$ & $\begin{array}{l}0.8 \mathrm{MHz} \text { (either } 0.8 \\
\text { or } 1.6 \mathrm{MHz} \text { for each } \\
\text { focal length, but } 0.8 \\
\text { most commonly } \\
\text { used) }\end{array}$ & $\begin{array}{l}140-240 \text { W } \\
\text { (200 W most } \\
\text { commonly } \\
\text { used) }\end{array}$ & continuous & single session \\
\hline $\begin{array}{l}\text { Orgera, } \\
2011[58]\end{array}$ & $\begin{array}{l}\text { Model-JC } \\
\text { HIFU } \\
\text { System }\end{array}$ & diameter $20 \mathrm{~cm}$; focal length $15 \mathrm{~cm}$ & $0.8 \mathrm{MHz}$ & $60-400 \mathrm{~W}$ & continuous & single session \\
\hline \multirow[t]{2}{*}{$\begin{array}{l}\text { Li, } 2012 \\
{[59]}\end{array}$} & $\begin{array}{l}\text { FEB-BY02 } \\
\text { HIFU } \\
\text { System }\end{array}$ & $\begin{array}{l}\text { aperture of } 37 \mathrm{~cm} \text {; focal distance } \\
25.5 \mathrm{~cm} \text {; focus has a } 6 \mathrm{~dB} \text { beam } \\
\text { width of } 1.6 \mathrm{~mm} \text { and an axial length } \\
\text { of } 1 \mathrm{~cm} \text {; effective therapy depth 2-- } \\
15 \mathrm{~cm}\end{array}$ & $1 \mathrm{MHz}$ & $\begin{array}{l}400-1000 \mathrm{~W} \\
\text { mean: } 586+/- \\
78.4 \mathrm{~W}\end{array}$ & pulsed & $\begin{array}{l}1.2 \text { average ( } 19 \text { patients had } 1 \\
\text { session, } 6 \text { patients had } 2 \\
\text { sessions) }\end{array}$ \\
\hline & & & $0.85 \mathrm{MHz}$ & N/A & continuous & \\
\hline
\end{tabular}


Table 4 HIFU Technical parameters (Continued)

\begin{tabular}{|c|c|c|c|c|c|c|}
\hline $\begin{array}{l}\text { Gao, } 2013 \\
{[60]}\end{array}$ & $\begin{array}{l}\text { Model-JC } \\
\text { HIFU } \\
\text { System }\end{array}$ & $\begin{array}{l}\text { diameter } 20 \mathrm{~cm} \text {; focal length } \\
13.5 \mathrm{~cm}\end{array}$ & & & & $\begin{array}{l}33 \text { patients had } 1 \text { session, } 4 \\
\text { patients had } 2 \text { sessions, and } \\
\text { others more than } 2 \text { sessions }\end{array}$ \\
\hline $\begin{array}{l}\text { Anzidei, } \\
2014[24]\end{array}$ & $\begin{array}{l}\text { ExAblate } \\
2100 ; \\
\text { InSightec }\end{array}$ & $\begin{array}{l}\text { diameter } 12 \mathrm{~cm} \text {; radius of curvature } \\
16 \mathrm{~cm} \text {; focal distance } 6-20 \mathrm{~cm}\end{array}$ & $0.95-1.35 \mathrm{MHz}$ & N/A & & single session \\
\hline $\begin{array}{l}\text { Sofuni, } \\
2014[61]\end{array}$ & $\begin{array}{l}\text { FEB-BY02 } \\
\text { HIFU } \\
\text { System }\end{array}$ & $\begin{array}{l}\text { aperture of the ultrasound array } \\
37 \mathrm{~cm} \text {; radius of curvature } 25.5 \mathrm{~cm}\end{array}$ & $1.1 \mathrm{MHz}$ & $\begin{array}{l}\text { input electric } \\
\text { power: } 0.5- \\
2 \mathrm{~kW}\end{array}$ & pulsed & $2.7+/-0.1 \mathrm{SD}$ \\
\hline $\begin{array}{l}\text { Marinova, } \\
\text { 2016a [23] }\end{array}$ & $\begin{array}{l}\text { Model-JC } \\
\text { HIFU } \\
\text { System }\end{array}$ & $20 \mathrm{~cm}$ diameter; focal length $15 \mathrm{~cm}$ & $0.8 \mathrm{MHz}$ & $\begin{array}{l}\text { range: } 80- \\
400 \text { W } \\
\text { average: } 344 \\
+/-72 \text { W (200- } \\
400)\end{array}$ & continuous & single session \\
\hline $\begin{array}{l}\text { Li YJ, } \\
2016 \text { [34] }\end{array}$ & N/A & N/A & $0.8 \mathrm{MHz}$ & $300 \mathrm{~W}$ & N/A & N/A \\
\hline $\begin{array}{l}\text { Li X, } 2016 \\
{[49]}\end{array}$ & $\begin{array}{l}\text { Model-JC } \\
\text { HIFU } \\
\text { System }\end{array}$ & N/A & N/A & N/A & N/A & single session \\
\hline $\begin{array}{l}\text { Strunk, } \\
2016[62]\end{array}$ & $\begin{array}{l}\text { Model-JC } \\
\text { HIFU } \\
\text { System }\end{array}$ & diameter $20 \mathrm{~cm}$; focal length $15 \mathrm{~cm}$ & $0.8 \mathrm{MHz}$ & $200-400 \mathrm{~W}$ & continuous & single session \\
\hline $\begin{array}{l}\text { Lv, } 2016 \\
{[48]}\end{array}$ & $\begin{array}{l}\text { JC200 } \\
\text { HIFU } \\
\text { System }\end{array}$ & focus $14.7 \mathrm{~cm}$ & $0.97 \mathrm{MHz}$ & $\begin{array}{l}\text { average: } \\
350 \mathrm{~W}\end{array}$ & continuous & $\begin{array}{l}\text { single treatment expected, but } \\
\text { additional treatments can be } \\
\text { added when necessary }\end{array}$ \\
\hline $\begin{array}{l}\text { Marinova, } \\
\text { 2016b } \\
{[36]}\end{array}$ & $\begin{array}{l}\text { Model-JC } \\
\text { HIFU } \\
\text { System }\end{array}$ & diameter $20 \mathrm{~cm}$; focal length $15 \mathrm{~cm}$ & $0.8 \mathrm{MHz}$ & N/A & continuous & single session \\
\hline
\end{tabular}

information. MRgFUS was performed in a single treatment session, whereas the USgFUS was often delivered in several sessions, with the number of sessions varying based on the device used, general health of the patient and size of the tumor to be ablated.

Post-operatively, the skin was evaluated for development of skin burns, and biochemical blood tests were used to monitor for the development of pancreatitis. Depending on the study's design and the authors' preferences, several imaging modalities were used immediately after HIFU and in the post-treatment period to assess ablation and tumor response.

\section{Discussion}

The origin of pain from pancreatic cancer is multifactorial, resulting from tumor infiltration of nerves, tumor mass compression and inflammatory reaction elicited by the malignancy $[25,26]$. The mechanisms by which HIFU relieves pain are not completely understood. Three possibilities have been proposed: 1) thermal damage to the nerves innervating the tumor, 2) fibrosis and shrinkage of the tumor after ablation, resulting in reduced mass effect, and 3) the inactivation of the fibers of the celiac plexus that normally transmit the pain sensation centrally [10].

Our study suggests that HIFU is a very effective mean of relieving pain in patients with pancreatic cancer.
Despite the heterogeneity in the studies published in the literature, $81 \%$ of patients had a partial or total decrease of pain following the treatment. Case reports published in the literature, excluded from our analysis because of their small sample size, are consistent with our findings on the efficacy and safety of HIFU for pain palliation [27-31].

Not all papers reported the duration of pain relief. The longest follow up period was reported by $\mathrm{Wu}$ et al., with no pain progression seen in a up to 17 months, and Anzidei et al., with pain alleviation persisting at 6 months $[24,32]$. Wang et al. and Li YJ et al. reported a median pain relief time of 10 weeks and 5.6 months, respectively $[33,34]$. Other studies with short-term follow up ( $\leq 3$ months) confirm the relief of pain $[23,35,36]$.

The main treatment proposed when opioids fail in pain control is currently neurolytic celiac plexus blockade (NCPB). NCPB involves percutaneous or endoscopic injection of anesthetics and neurolytic substances (Ethanol or Phenol) along the celiac plexus in order to interrupt nociceptive transmission [25]. The actual efficiency in the reduction of pain is variable and, in some studies, it has been questioned [13, 37]. Although response rates as high as 70-90\% were initially reported [12], a subsequent metaanalysis of five randomized control trial demonstrated only a $6 \%$ reduction in pain scores after neurolytic celiac plexus blockade [13]. NCPB has also been reported to result in 
reduced opioid use and related side effects [37-39]. However, Wong et al., in a double blinded randomized control trial that compare NCPB to a placebo, found no difference in opiate use or side effects between the two groups [40]. Most of the studies found a short duration of analgesia, lasting about 3 months [38, 39, 41, 42], with repeated NCPB demonstrating reduced efficacy (29\% in repeated vs $67 \%$ after initial block) [42]. Indeed, the most commonly encountered side effects in NCPB include: local pain (96\%), transient diarrhea (44\%) and hypotension (36\%) $[12,41]$. More severe adverse events occur in $2 \%$ of patients, including but not limited to: pneumothorax, shoulder, chest and pleuritic pain. One percent of these complications are neurological, with occurrence of paraplegia representing the major concern [12, 41].

Focused ultrasound technology appears to be an attractive alternative because it is non-invasive, provides rapid pain relief and has a high safety profile [10], it has also been used successfully after NCPB has failed [24]. It offers the potential for a multimodal therapeutic approach for patients with pancreatic cancer, providing pain palliation and the possibility of local tumor control and increased local delivery of chemotherapeutic agents [15]. Compared with neurolytic celiac plexus blockade, the rate of adverse effects in our studies was considerably lower. HIFU has a high safety profile, with only eight cases of severe complications (1.3\%) reported in our analysis. In a study published by Jung et al., the adverse events after HIFU treatment for hepatic and pancreatic cancer were listed. Among them, there were skin redness, edema and pain in the treated region; for the 35 patients with pancreatic cancer treated with HIFU, 3rd-degree skin burn $(n=1,2.9 \%)$ and fistula formation between the tumor and the duodenum were listed as major complications $(n=3,8.5 \%)$ [43]. In our studies, the most common side effect encountered is mild to severe abdominal pain, followed by skin burns of various degree. The abdominal pain is usually selflimited, with only one case requiring hospitalization. The most feared adverse event following HIFU is bowel perforation due to interposition of the intestinal loops along the ultrasound beam pathway; two cases of pancreaticoduodenal fistula (0.3\%) occurred among our patients. Eight patients developed mild or transient pancreatitis (1.3\%) classified as minor complication, in nine further patients there was a mild increase of lipase on blood analysis without any clinical signs of pancreatitis (1.4\%). Unlike chemotherapy, HIFU does not have systemic side effects that limit dose or number of applications and in contrast to radiation therapy, it is not a risk for poor wound healing or secondary malignancies.

In these studies, local tumor control achieved after HIFU was assessed through different imaging methods. Among 639 patients who underwent HIFU for pancreatic cancer, 455 had a positive tumor response excluding two studies not reporting this data (Table 3). These studies reveal that tumor response is not always correlated to pain relief, suggesting that complete ablation is not necessary for pain relief. Xiong et al. observed pain improvement in $88 \%$ of patients who had an objective tumor response but also in $76.2 \%$ of patients who did not [44]. Similarly, Zhao et al. observed pain relief in $88.2 \%$ of patients with a tumor response and in $35 \%$ of patients with stable or progressive disease [45]. Tumor size reduction does not appear to be a sensitive way to evaluate HIFU efficacy, neither in terms of the effect on pain relief nor for the evaluation of successful ablation. Indeed, in the short term, despite the reduction in pain, the volume of the mass may appear unchanged or increased due to local edema [46, 47].

Pancreatic adenocarcinoma is relatively hypovascular and is surrounded by a thick fibrous ring that limits the penetration and diffusion of chemotherapeutic agents, accounting in part for the poor responsiveness to pharmacological treatment. Recent studies have demonstrated that HIFU may have a synergistic effect with chemotherapy, boosting the drug concentration in the tumor and reducing the systemic toxicity. The underlying mechanisms proposed are increased permeability of vascular endothelial cells and enhanced diffusion of the chemotherapeutic agent under the radiation force from the ultrasound field [15]. Among the studies included in our analysis, two compare the combination treatment of HIFU plus chemotherapy to chemotherapy alone. $\mathrm{Lv}$ et al. conclude that the difference in pain relief between the two groups was significantly improved in the HIFU combination group (65.2\% vs $31.8 \%)$; although the disease control rate was also higher in the HIFU group $(78.2 \%$ vs $59.0 \%)$, this was not statistically different. Moreover, the combination therapy was associated with considerably improved survival rates at 6 months (73.9\% vs $40.9 \%, P<0.05)$, but not at 12 months $(13.0 \%$ vs $4.5 \%, P>0.05)$ [48]. Li X et al. reported similar results with a significant better overall survival (10.3 months vs 6.6 months), PFS (Progression Free Survival: 5.1 months vs 2.3 months), objective tumor response $(26.2 \%$ vs $8.5 \%$ ), and remission rate of pain ( $57 \%$ vs $20 \%$ ) [49].

Good control of pain relief has a significant impact on the quality of life of the patient, but further studies are needed to assess the potential that this may have on survival. Survival benefit following HIFU has been previously reported in the literature. Vidal et al. observed an unexpectedly prolonged survival time for patient with stage III and stage IV pancreatic carcinoma treated with HIFU and chemotherapy, with the longest survival of 3.4 years. Moreover, the estimate of the survival was surprisingly high, with $33.5 \%$ pancreatic cancer patients still alive at 4.2 years [50]. HIFU was combined with 
gemcitabine in this study; considering the absence of a control arm, it is possible that the improved survival partially reflects patients that responded well to chemotherapy. Most of the studies included in our analysis have not been designed to assess the survival benefit of HIFU in the treatment of advanced pancreatic cancer. The median overall survival is reported in 12 studies; the range is $7-25$ months with a median value of 10 months. These data are very heterogeneous with no definition of a starting point nor duration of follow-up. Moreover, some of the papers report survival after HIFU-only while others after HIFU combined with other treatments. Clearly, further research is needed to validate these results.

The main limitation in our study is the lack of randomized controlled trials and the considerable heterogeneity in the data reported by the single papers, which sometimes made comparison of the results not feasible. The most important differences were in the evaluation of pain, assessment of tumor response and technique used for the treatment. It was not possible for us to estimate quantitatively the reduction of pain following HIFU, as most of the papers did not use a numerical scale to assess the difference at baseline and follow up. Moreover, the timing of pain evaluation was not consistent, while precise intervals would allow an estimate of pain relief in the long term. A considerable heterogeneity was observed in the use of analgesic drugs, in terms of need of pain medications after treatment, opioid or non-opioid use, and eventual doses required. Some studies defined pain relief considering only the absolute decrease in pain, while others included the change in analgesic drugs need. Likewise, the tumor response evaluation differed in the criteria, timing and methodology used to evaluate it. A more consistent follow up time is necessary to assess longer term results and to address the potential survival benefit following HIFU. Uniformity is needed in the inclusion criteria used and in the description of the characteristics of the tumor treated (histological type, location, size, stage) in order to make data more homogeneous and comparable.

Most of the current literature reports experience with USgFUS, and few reports suggest the feasibility and safety of MRgFUS. The US guided methodology uses ultrasound for both the detection and ablation of the lesion, allowing identification of potential obstructions in the US beam pathway, such as air. USgFUS has some limitations: its contrast resolution may not be adequate to depict accurately the borders of the lesion, it lacks a real-time temperature monitoring to ensure adequate ablation, and it is operator dependent. MRgFUS is promising, because of improved tissue contrast allowing definition of the tumor and surrounding structures and because of real time MR thermometry, which allows better targeting and monitoring of the ablated region $[16,46,51,52]$.
Even though most of the studies were performed with US guided HIFU, standardization of energy, power and technical parameters are lacking, and still needed to obtain the best results at the minimum risk for the patient. The studies included used two different US systems; indeed, the biological effect of continuous wave HIFU can have considerable differences from the pulsed wave focused ultrasound in terms of biological effects on the tissue, interaction with other therapeutic regimens and clinical response of the patient. Not all papers specified if HIFU was applied alone or with concurrent chemotherapy/radiotherapy. In the future, these data need to be specified to better discriminate the potential of HIFU as single therapy and the effects of combination therapies on tumor response.

Therefore, there is need for uniformly designed studies in order to determine the data necessary to report in each trial, in order to objectively evaluate the treatment results. A clinical registry of the results of HIFU treatment of pancreatic cancer is planned. This will provide an analytical tool useful to assess the eventual benefit of HIFU on the overall survival and pain palliation in pancreatic cancer, which is still a poorly treated aggressive tumor bearing a poor prognosis.

\section{Conclusions}

Although the literature is heterogeneous, our study supports that High Intensity Focused Ultrasound is a potent tool for pain palliation in unresectable pancreatic cancer. The potential role of HIFU requires further well designed studies to confirm its efficacy, safety and advantages compared to other palliative techniques.

\section{Abbreviations \\ HIFU: High intensity focused ultrasound; MRgFUS: MR guided focused ultrasound; NCPB: Neurolytic celiac plexus blockade; USgFUS: US guided focused ultrasound}

Acknowledgements

Not applicable.

Availability of data and materials

The datasets used and/or analyzed during the current study available from the corresponding author on reasonable request.

Authors' contributions

Not applicable.

\section{Competing interests}

This work was supported by FUSF Global Internship Program 2015 and PO1 CA159992. The authors declare that they have no competing interests.

Consent for publication

Not applicable.

Ethics approval and consent to participate

Not applicable.

Author details

${ }^{1}$ Medical Student, Sapienza University of Rome, School of Medicine, V.le Regina Elena, 324, 00180 Rome, Italy. ${ }^{2}$ Department of Radiology, Lucas 
Center for Imaging, Stanford University School of Medicine, 1201 Welch Road, Stanford, CA 94305, USA. 'Department of Radiological Sciences, MRgFUS \& Cardiovascular Imaging Unit, Sapienza University of Rome, School of Medicine, V.le Regina Elena, 324, 00180 Rome, Italy. ${ }^{4}$ Gastroenterology Section, Harborview Medical Center, Bioengineering and Radiology, University of Washington, Box 359773325 Ninth Avenue, Seattle, WA 98104, USA.

\section{Received: 22 October 2016 Accepted: 6 January 2017} Published online: 01 April 2017

\section{References}

1. Siegel RL, Miller KD, Jemal A. Cancer statistics, 2016. CA Cancer J Clin. 2016;66:7-30. doi:10.3322/caac.21332.

2. $\mathrm{NIH}$. Available online: $\mathrm{http}: / /$ seer.cancer.gov/statfacts/html/pancreas.html (accessed on 8 Oct 2016).

3. Smyth E, Cunningham D. Pancreatic cancer. Harrison's Principles Int Med. 2015:2(19th):554-7.

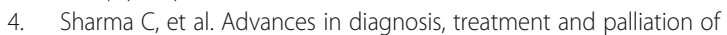
pancreatic carcinoma: 1990-2010. World J Gastroenterol. 2011:17(7):867-97.

5. Siegel R, Naishadham D, Jemal A. Cancer statistics, 2013. CA Cancer J Clin. 2013;63(1):11-30

6. Zuckerman DS, Ryan DP. Adjuvant therapy for pancreatic cancer. Cancer 2008;112(2):243-9.

7. Hidalgo M. Pancreatic cancer. N Engl J Med. 2010;362(17):1605-17

8. Reddy SK, Elsayem A, Talukdar R. Supportive care: symptom management. Jones and Bartlett: Pancreatic Cancer. Sudbury; 2005. p. 479-98.

9. Caraceni A, Portenoy RK. Pain management in patients with pancreatic carcinoma. Cancer. 1996;78(3):639-53

10. Zhou Y. High-intensity focused ultrasound treatment for advanced pancreatic cancer. Gastroenterol Res Pract. 2014;2014:205325. doi:10.1155/2014/205325.

11. Cherny $N$, et al. Strategies to manage the adverse effects of oral morphine: an evidence-based report. J Clin Oncol. 2001:19(9):2542-54.

12. Eisenberg E, Carr DB, Chalmers TC. Neurolytic celiac plexus block for treatment of cancer pain: a meta-analysis. Anesth Analg. 1995:80(2):290-5.

13. Yan BM, Myers RP. Neurolytic celiac plexus block for pain control in unresectable pancreatic cancer. Am J Gastroenterol. 2007;102(2):430-8.

14. Tempany CM, Mcdannold NJ, Hynynen K, Jolesz FA. Focused ultrasound surgery in oncology: overview and principles. Radiology. 2011;259(1):39-56. doi:10.1148/radiol.11100155.

15. Jang HJ, et al. Current and future clinical applications of high-intensity focused ultrasound (HIFU) for pancreatic cancer. Gut Liver. 2010:4 Suppl 1:S57-61.

16. Khokhlova TD, Hwang JH. HIFU for palliative treatment of pancreatic cancer. J Gastrointest Oncol. 2011;2(3):175-84.

17. Zhou YF. High intensity focused ultrasound in clinical tumor ablation. World J Clin Oncol. 2011;2(1):8-27.

18. Wu F. High intensity focused ultrasound: a noninvasive therapy for locally advanced pancreatic cancer. World J Gastroenterol. 2014;20(44):16480-8.

19. Moher D, Altman DG, Liberati A, et al. PRISMA statement. Epidemiology. 2011:22:128. author reply.

20. Wang $X$, Sun J. High-intensity focused ultrasound in patients with late-stage pancreatic carcinoma. Chin Med J. 2002:115(9):1332-5.

21. Gu Y-Z, et al. Application of high intensity focused ultrasound in treating 45 cases of carcinoma of pancreas. Fudan Univ J Med Sci. 2004;31(2):135-7.

22. Li G, et al. A clinical study on HIFU combined with chemotherapy in treating patients with advanced abdominal and pelvic malignant tumors. Chin J of Pract Med. 2004;3(8):679-82

23. Marinova M, et al. High-intensity focused ultrasound (HIFU) for pancreatic carcinoma: evaluation of feasibility, reduction of tumour volume and pain intensity. Eur Radiol. 2016;26(11):4047-56.

24. Anzidei $M$, et al. Magnetic resonance-guided high-intensity focused ultrasound treatment of locally advanced pancreatic adenocarcinoma: preliminary experience for pain palliation and local tumor control. Investig Radiol. 2014;49(12):759-65.

25. Sehgal S, Ghaleb A. Neurolytic celiac plexus block for pancreatic cancer pain: a review of literature. Indian J Pain. 2013;27(3):121

26. Penman ID, Gilbert D. Basic technique for celiac plexus block/neurolysis. Gastrointest Endosc. 2009;69(2):S163-5.
27. Yuan $Y$, et al. Multidisciplinary treatment with chemotherapy, targeted drug, and high-intensity focused ultrasound in advanced pancreatic carcinoma. Med Oncol. 2012;29(2):957-61.

28. Zhu X, et al. Metastatic adenocarcinoma of the epididymis from pancreatic cancer successfully treated by chemotherapy and high-intensity focused ultrasound therapy: a case report and review of the literature. Pancreas. 2011;40(7):1160-2.

29. Lau PC-P, et al. Inoperable pancreatic adenocarcinoma rendered complete remission by high-intensity focused ultrasound concurrent with gemcitabine-capecitabine chemotherapy: case report and topic review. J Dig Dis. 2012;13(1):60-4.

30. Anzidei $M$, et al. Magnetic resonance-guided focused ultrasound ablation in abdominal moving organs: a feasibility study in selected cases of pancreatic and liver cancer. Cardiovasc Intervent Radiol. 2014;37(6):1611-7.

31. Dimitrov D, et al. Multimodality treatment by FOLFOX plus HIFU in a case of advanced pancreatic carcinoma. A case report. JOP. 2015;16(1):66-9.

32. Wu F, et al. Feasibility of US-guided high-intensity focused ultrasound treatment in patients with advanced pancreatic cancer: initial experience 1. Radiology. 2005;236(3):1034-40.

33. Wang K, et al. Analgesic effect of high intensity focused ultrasound therapy for unresectable pancreatic cancer. Int J Hyperth. 2011;27(2):101-7.

34. Li Y-J, Huang G-L, Sun X-L, Zhao X-C, Li Z-G. The combination therapy of high-intensity focused ultrasound with radiotherapy in locally advanced pancreatic carcinoma. World J Surg Oncol. 2016;14:60. doi:10. 1186/s12957-016-0809-5.

35. Sung HY, et al. Long-term outcome of high-intensity focused ultrasound in advanced pancreatic cancer. Pancreas. 2011;40(7):1080-6.

36. Marinova M. et al. High-intensity focused ultrasound (HIFU) for tumor pain relief in inoperable pancreatic cancer: Evaluation with the pain sensation scale (SES). Schmerz. 2016

37. Mercadante S. Celiac plexus block versus analgesics in pancreatic cancer pain. Pain. 1993;52(2):187-92.

38. Polati $\mathrm{E}$, et al. Prospective randomized double-blind trial of neurolytic coeliac plexus block in patients with pancreatic cancer. Br J Surg. 1998;85(2):199-201.

39. Lillemoe KD, et al. Chemical splanchnicectomy in patients with unresectable pancreatic cancer. A prospective randomized trial. Ann Surg. 1993;217(5):447.

40. Wong GY, et al. Effect of neurolytic celiac plexus block on pain relief, quality of life, and survival in patients with unresectable pancreatic cancer: a randomized controlled trial. Jama. 2004;291(9):1092-9.

41. Ischia S, et al. Three posterior percutaneous celiac plexus block techniques. A prospective, randomized study in 61 patients with pancreatic cancer pain Anesthesiology. 1992;76(4):534-40.

42. McGreevy K, et al. The effectiveness of repeat celiac plexus neurolysis for pancreatic cancer: a pilot study. Pain Practice. 2013;13(2):89-95.

43. Jung SE, et al. High-intensity focused ultrasound ablation in hepatic and pancreatic cancer: complications. Abdom Imaging. 2011;36(2):185-95.

44. Xiong $L L$, et al. Early clinical experience using high intensity focused ultrasound for palliation of inoperable pancreatic cancer. Jop. 2009:10(2):123-9.

45. Zhao $\mathrm{H}$, et al. Concurrent gemcitabine and high-intensity focused ultrasound therapy in patients with locally advanced pancreatic cancer. Anti Cancer Drugs. 2010;21(4):447-52

46. Wu F. Extracorporeal high intensity focused ultrasound in the treatment of patients with solid malignancy. Minim Invasive Ther Allied Technol. 2006; 15(1):26-35.

47. Khokhlova TD, Hwang JH. "HIFU for Palliative Treatment of Pancreatic Cancer." Therapeutic Ultrasound. Springer International Publishing; 2016; $83-95$.

48. LV W, et al. High-intensity focused ultrasound therapy in combination with gemcitabine for unresectable pancreatic carcinoma. Ther Clin Risk Manag. 2016;12:687

49. Li $X$, et al. Retrospective analysis of high intensity focused ultrasound combined with S-1 in the treatment of metastatic pancreatic cancer after failure of gemcitabine. Am J Cancer Res. 2016;6(1):84

50. Vidal-Jove J, Perich E, del Castillo MA. Ultrasound guided high intensity focused ultrasound for malignant tumors: the Spanish experience of survival advantage in stage III and IV pancreatic cancer. Ultrason Sonochem. 2015;27:703-6.

51. Jolesz FA. MRI-guided focused ultrasound surgery. Annu Rev Med. 2009;60:417

52. Napoli A, et al. MR-guided high-intensity focused ultrasound: current status of an emerging technology. Cardiovasc Intervent Radiol. 2013;36(5):1190-203. 
53. Xiong $L L$, et al. The preliminary clinical results of the treatment for advanced pancreatic carcinoma by high intensity focused ultrasound. Chin J Gen Surg. 2001;16(6):345-7.

54. $\mathrm{Xu} Y \mathrm{YQ}$, et al. The acesodyne effect of high intensity focused ultrasound on the treatment of advanced pancreatic carcinoma. Clin Med J China. 2003;10:322-3.

55. Yuan C-J, Yang L, Cheng Y. Observation of high intensity focused ultrasound treating 40 cases of cancer of pancreas. Chin J Clin Hep. 2003;19(03):145-6

56. Xie $B$, et al. The efficacy of high-intensity focused ultrasound (HIFU) in advanced pancreatic cancer. Chin J Clin Oncol. 2008:5(3):183-6.

57. Orsi F, et al. High-intensity focused ultrasound ablation: effective and safe therapy for solid tumors in difficult locations. Am J Roentgenol. 2010;195(3):W245-52.

58. Orgera G, et al. High-intensity focused ultrasound (HIFU) in patients with solid malignancies: evaluation of feasibility, local tumour response and clinical results. La radiologia medica. 2011;116(5):734-48.

59. Li P-Z, et al. High-intensity focused ultrasound treatment for patients with unresectable pancreatic cancer. Hepatobiliary Pancreat Dis Int. 2012;11(6):655-60

60. Gao HF, et al. High intensity focused ultrasound treatment for patients with local advanced pancreatic cancer. Hepato Gastroenterology. 2013;60(128):1906-10.

61. Sofuni A, et al. Safety trial of high-intensity focused ultrasound therapy for pancreatic cancer. World J Gastroenterol. 2014;20(28):9570-7.

62. Strunk HM, et al. Clinical use of High-Intensity Focused Ultrasound (HIFU) for tumor and pain reduction in advanced pancreatic cancer. RöFo. 2016;188(7):662-70.

\section{Submit your next manuscript to BioMed Central and we will help you at every step:}

- We accept pre-submission inquiries

- Our selector tool helps you to find the most relevant journal

- We provide round the clock customer support

- Convenient online submission

- Thorough peer review

- Inclusion in PubMed and all major indexing services

- Maximum visibility for your research

Submit your manuscript at www.biomedcentral.com/submit 